\title{
Information Sources for Two-wheeler Purchase: An Analytical Study with Special Focus on Malappuram District of Kerala
}

\author{
K. P Najeemudeen ${ }^{1, *}$, N. Panchanatham ${ }^{2,3}$ \\ ${ }^{1}$ Jawaharlal Business School, Karpagam University, India \\ ${ }^{2}$ MBA Department, Annamalai University, India \\ ${ }^{3}$ Karpagam University, India
}

Copyright $(2016$ by authors, all rights reserved. Authors agree that this article remains permanently open access under the terms of the Creative Commons Attribution License 4.0 international License

\begin{abstract}
Information is an important aspect in our life. Information or knowledge about the product he intends to purchase is very important for a customer. Similarly, knowledge about the sources from where the customers are getting information is very vital for a marketer for channelizing his marketing communications in such a way that it will reach his target customers in the right way at minimal cost. In that context, the present study is intended to investigate and identify the information sources through which customers are gathering information on two-wheelers and the relative importance of these sources on their purchase decision. This study also tends to analyze the effects of the socio-economic characteristics of consumers on these information sources. This study is based on a questionnaire survey conducted among 681 Two-wheeler users in Malappuram district of Kerala. Statistical tools like Chi-square analysis, ANOVA, Z-Test, Multiple Correlation, Multiple Regression and Friedman Test has been used for the meaningful analysis and interpretation of data. This study will be a ready reckoner for the two-wheeler manufacturing companies and dealers to identify the sources of information which the customers consider to be the most reliable and highly influential in their selection of two-wheeler brands/models. The findings of this study will equip them to make their marketing efforts to be more customers centric and will also facilitate them in the selection of the right medium for communicating with the customers.
\end{abstract}

Keywords Information Sources, Customer Awareness, Two-Wheeler, Bike, Scooter, Automobile

\section{Introduction}

Information refers to the bundle of knowledge or facts on a person, product, process, event or anything. Information is conveyed either as the content of a message or through direct or indirect observation of something. Information Search is a stage in the Consumer Decision Process during which a consumer searches for internal or external information.

According to Philip Kotler, the buying process starts when the buyer recognizes a problem or need. This need can be triggered by internal stimuli (such as feeling hunger or thirst) or external stimuli (such as seeing an ad) that then becomes a drive. He also says that an aroused consumer who recognizes a problem will be inclined to search for more information. If the consumer's drive is strong and a satisfying product is near at hand, the consumer is likely to buy it then. If not, the consumer may simply store the need in memory or undertake an information search related to the need.

Kotler distinguishes between two levels of arousal. At the milder search state of heightened attention, a person simply becomes more receptive to information about a product. For example, a person who intends to buy a two-wheeler will become more receptive to information about two-wheelers in this stage. He pays attention to two-wheeler ads, two-wheelers used by friends and two-wheeler related conversations. At the active information search level, he may go into active information search, in which he looks for reading materials on two-wheelers, discuss with friends, surf the internet, visit two-wheeler dealers, collect the feedbacks from existing two-wheeler users and seeks expert opinion from two-wheeler salesmen, two-wheeler mechanics etc. The amount of searching he does will depend upon the strength of his drive for a two-wheeler, the amount of information he starts with, the ease of obtaining more information, the value he places on additional information and the satisfaction he gets from searching. Normally the amount of consumer search activity increases as the consumer moves from decisions that involve limited problem solving to those that involve extensive problem solving. 
Kotler categorizes consumer information sources in to four, namely, personal sources (family, friends, neighbors, acquaintances), commercial sources (advertising, web sites, salespersons, dealers, packaging, displays), public sources (mass media, consumer-rating organizations), and experiential sources (handling, examining, using the product). The relative influence of these information sources varies with the product and the buyer. The consumer usually receives the most information from commercial (marketer-dominated) sources, although the most influential information comes from personal sources. Commercial sources normally inform the buyer, but personal sources legitimize or evaluate products for the buyer. Through gathering information, the consumer learns more and more about competing brands. As more information is obtained, the consumer's awareness and knowledge of the available brands and features increases. (Kotler, 2002).

\section{Major Sources of Information about Two-wheelers}

In today's technologically integrated world there are so many sources through which the customers can get information on a product, its uses, features, benefits, offers, schemes etc. Modern day customers are very keen to collect information from all the available sources before making their final purchase decision and they are also showing a tendency to share this information with others. In the case Two-wheelers also there are so many sources of information to the customers. Let us analyze them in a nutshell.

\section{Advertisements}

It is a well-known fact that Advertisements are the most effective source of imparting product knowledge to the customers. Advertising is the powerful instrument to choose the peoples' choice. Advertisements also have power like: the power to choose, the power to think for themselves, and the power to influence others. (Allen and Semenik, 2003). Now days all major Two-wheeler manufacturers are advertising their bikes and scooters in televisions, newspapers, internet etc. They are spending enormous amount of money for advertising every year. For example: Hero Motocorp has spent Rs.669 crores (2.42 percent of their annual revenue) for advertising in the financial year ended March 2015 compared to Rs.494 crores the previous year. During the same period Bajaj Auto Limited has spent Rs.321 crores (1.48 percent of their annual revenue) for advertising compared to Rs.262 crores the previous year. These two companies ranked $2^{\text {nd }}$ and $5^{\text {th }}$ in the list of Top 5 automobile companies of India in terms of advertisement expenditure during the financial year ended March 2015 (Business Standard, September 1, 2015). According to a survey report by TAM AdEx in 2001, the advertisements by Two-wheeler companies ranked $8^{\text {th }}$ in the list of Top 10 categories of television advertisements. Senthil Kumar et.al in their study emphasizes that the buying decisions and information search are strongly influenced by the two wheeler advertisement. The customers are meticulous in verifying the product characteristics displayed in the advertisement after their purchase.

\section{Review Shows in Television}

Automotive review shows in televisions have come a long way during the last ten years. There are at least 30 incredible automotive-themed television shows telecasting in various Indian television channels today. Some focus on road and track testing, some on adventures and some on the aesthetic as well as technical features of the vehicles. They take a long time to plan, film and edit and are also expensive to make. It will be a risky proposition to rate which of these shows is the best for the real automobile enthusiasts. There are many regular viewers to these programmes who are very keen to see all the latest vehicles in the market and to know more about them. Over Drive (CNBC-TV18/Awaaz), Car \& Bike Show (NDTV), Wheelocity (Zee Business), Times Drive (Times Now), Fast Track (Manorama News), Smart Drive (Asianet News), First Drive (Mathrubhumi Television), Bike \& Cars (Amrita TV) are some of the top rated automotive review shows in Indian televisions.

\section{News Paper Reports \& Review Articles}

Now days, almost all newspapers use to dedicate a special page or column for the current updates on automobiles. They use to give news items on vehicle launches, sales figures, upcoming vehicle models, gist of company reports, reviews of latest models, customer feedbacks etc in these pages/columns which are regularly followed by many a number of automobile enthusiasts. We cannot come along a single newspaper in India, which doesn't have a page/section for automobiles. Some newspapers have sequentially extended these columns and pages to special booklets/supplements and there to dedicated automotive magazines. Readers get updated on the latest developments in the automobile industry from these reports and articles and get influenced by what they read in their decision to buy cars or two-wheelers.

\section{Dealers}

Dealers are certainly one among the most important sources of information on two-wheelers. Customers who are intended to buy a two-wheeler or those wanted to know more about two-wheelers can make a walk in to a two-wheeler showroom from where they will get a deep pool of information about the brand and models of two-wheelers traded by that dealer. The sales people at the dealerships will provide them the necessary information such as features of different models, price, benefits, offers, finance facilities, mode of purchase etc. Customers can also see the different model of two-wheelers, touch it, feel it and even make a test drive to get more clear knowledge of the two-wheeler models. A major drawback of the information received from dealerships is that they may be biased. The 
dealer may provide some exaggerated information about his own brand by hiding its negative attributes and speaking badly about his rival brands to lure the customer to purchase from him.

\section{Automotive Magazines}

Today there are more than 1000 automotive magazines pan India that provide the most updated information on latest model of vehicles, statistical data and figures on automotive sales, import and export, news items on vehicle launches, upcoming vehicle models, test drive reports, user reviews and feedbacks on latest models, customer feedbacks etc. They also facilitate the comparison of the vehicles from different brands in the same segment which may enable the customer to choose the vehicle that suits him the best. The well covered features in these magazines with colour photos, figures, charts and graphs are a great source of information to many a number of automobile enthusiasts and customers. Top Gear, Over Drive, Fast Track, Auto Bild, Auto Express, Business Standard Motoring, Motor India, Zigwheels, Auto Today, and xBhp are examples of automotive magazines in India with a wide readership base. There are also some magazines that provide exclusive information on Two-wheelers like Bike India, Super Bike, Hot Bike, Rider, Ignition, Dirt Bike etc.

\section{Two-wheeler Mechanics}

Mechanics are dealing with different types of vehicles daily. Hence there is a general perception that the mechanics tend to know the pros and cons of all brands and models of vehicles. As a result we can see an increasing tendency of seeking the advice and suggestions of the mechanics for making a purchase decision. Let it be a bike, scooter, car or even a car. It is a fair truth that mechanics are becoming the prime opinion givers for the purchase of automobiles. Some automobile companies have even started the practice of giving incentives to the automobile mechanics for giving favourable feedback on their vehicles to the customers and induce them to purchase their brand.

\section{Internet}

According to 'Internet in India 2015' Report released by the Internet and Mobile Association of India (IAMAI) and IMRB International, the number of Internet users in India is expected to reach 462 million by 2016, registering a growth of 49 per cent over the previous year. High internet penetration across tier-II and tier-III cities along with rising disposable income shall lead to approximately 80 million transactions on the internet by 2020 . In this scenario, the number customers accessing internet for getting information about the products they intend to purchase has also witnessed a tremendous increase. Similarly in the case of two-wheelers also there is an increasing tendency among the prospective customers to rely on the internet for collecting information related to its features, price, user feedback, test drive reports etc. Apart from the official websites of the two-wheeler manufacturers, today there are many other websites and portals to help the customers for this purpose such as www.bikeportal.in, www.bikeindia.in, www.zigwheels.com, www.drivespark.com, www.gaadi.com, www.xbhp.com, www.infibeam.com, www.compareindia.ibnlive.com, www.mouthshut.com etc. Moreover many companies have started their own official social media pages with some contents which are highly useful to the customers like vehicle service and maintenance guidelines, driving safety guidelines etc. Last but not the least, today's new generation customers are interacting with their social media friends in Facebook and Twitter about their two-wheeler purchase intentions and are seeking the suggestions and recommendations from them. Many of them also use to share their own personal experiences of two-wheeler purchase in their posts.

\section{Existing Users}

People who are already using a product are the best option for getting the actual feedback or review about any product. That is very well applicable in case of Two-wheelers too. Being the regular users of a particular brand or model of a two-wheeler they know its merits and demerits well and the reliability of the information they provide will also be very high. A person who plans to buy a two-wheeler can directly approach the existing two-wheeler users instead of wasting his time on other sources and get the most accurate and unprejudiced information from them that may be very useful for his buying decision.

\section{Word of Mouth Publicity}

Word of Mouth Publicity is an oral or written recommendation by a satisfied customer to the prospective customers of a good or service. It is an unpaid form of promotion in which satisfied customers tell other people how much they like a business, product or service. According to Nielsen, $92 \%$ of consumers believe recommendations from friends and family over all forms of advertising. In a recent study, $64 \%$ of marketing executives indicated that they believe word of mouth is the most effective form of marketing. This type of communication may either be based on the personal experience of a person or on the basis of what he learned from another person. A prospective customer for two-wheeler can listen to this word of mouth communications roaming around for taking a buying decision.

This study is intended to find out which of these information sources are mainly approached by the prospective customers and their relative influence on their purchase decision.

\section{Review of Literature}

Basavaraj H. Huggi (2016) in his paper 'Recent Trends in Consumer Satisfaction towards TVS Motors with Special Reference to Ranebennur City' attempted to measure the 
consumers buying behavior towards different models of TVS two-wheelers, the factors influencing the consumers to purchase TVS two-wheelers, consumers' level of satisfaction towards TVS two-wheelers and also the problems faced by the consumers while using the TVS two-wheelers. According to this study Television Ads, Internet and Hoardings are the biggest sources of information on two-wheelers to the customers. Bhuvanesh Kumar and Kavitha (2015) undertook a study titled 'Customer Satisfaction towards Honda Activa with Special Reference to Pollachi Taluk', with an aim to identify the factors influencing consumers to purchase Honda Active and also to study the effect of advertisement on the purchase decision of the customers. This study revealed that advertisements play a vital role in the purchase decision of the customers and hence the frequency of Ads shall be increased to create a rapid impact in their minds that lasts for a long time. Chandu Ravi Kumar and N.D.N Swamy (2015) made an empirical study titled 'A Study on Consumer Satisfaction towards TVS Motors with Special Reference to Guntur City' to measure the consumers buying behavior towards the different models of TVS two-wheelers and to study the factors influencing the consumers to purchase the TVS two-wheelers. As per their findings television is the biggest source of information regarding two-wheelers followed by internet and hoardings. Duggani Yuvaraju and Durga Rao S (2014) conducted a study on 'Customer Satisfaction towards Honda Two Wheelers: A Case Study in Tirupati' to find out the factors that have influence on customers, when they are purchasing Honda bikes. According to their findings TV Ads are a main source of product awareness to the customers followed by dealers, newspapers and friends.

Chauhan V.S (2015) in his study 'A Research Paper on Impact of Social Media on Sales Promotion - A Case Study on Indian Automobile Industry' discusses the various types of social media and its impact on sales promotion and how this would affect individuals and organizations in their buying decisions. This study inferred that social media does have a significant impact on the sales and sales promotion of automobiles. Ketan Kamra (2015) in his paper 'Influence of Social Media on the Indian Automotive Consumers: Primary Study in National Capital Region' ventured to identify and investigate the extent of influence of social media in the Indian Automotive Consumers by conducting a thorough primary research. The results reveal a strong influence of social media in influencing the consumers over multiple buying processes parameters. Influence of social media on vehicular research, suggestions, vehicle technologies, finance calculator and Facebook page marketing have showed a significant share in impacting a consumer before buying an automobile. Fahmeeda Yasmeen (2015) made a study on 'Consumer Behaviour towards Brand Positioning of Two-Wheeler Bikes in Chennai City', to identify the factors influencing consumers in the selection and purchase of a particular brand of two-wheeler. It was also found that the decision to buy a particular brand was mostly influenced by parents and friends. The television also plays an important role in influencing the customers to buy a particular brand of two-wheeler.

Priyanka Jain (2015) in her research paper 'A Study of Customer Satisfaction of Two Wheelers on Yamaha' tries to find the customer satisfaction level towards Yamaha two-wheeler vehicles. The findings revealed that friends are the major influencers in buying decision making process. Sirajudeen M. and Leyakath Ali Khan U. (2015) made a study titled 'An Empirical Study on Brand Position among Two-wheeler Motorcycles in Tiruchirapalli District', to identify the brand position among two-wheelers in Tiruchirappalli District and also to analyze the importance of various promotional tools in the purchase of two wheelers. 'Word of mouth' was pointed out to be the major factor that influence the purchase decision for two-wheelers followed by magazines, television, internet, newspaper, test ride, radio and exchange melas. Trinankur Dey and Dr. L. S. Sharma (2015) in their study 'An Empirical Study of Buying Behavior of the Two Wheeler Consumers in Agartala City' attempted to enquire about the purchasing motives of the two wheeler customers in Agartala city. The analysis has also shown that the customers are influenced by word of mouth by peer groups and, to some extent, by the salespersons at the point of purchase. Velumani M. (2015), in his study titled 'A Study on Consumer Buying Behaviour and Satisfaction Level of Two-wheeler with Reference to Suzuki Motorcycle at Erode', identified the consumer buying behavior and satisfaction level of Suzuki motorcycle at Erode. According to this study customers are using multiple sources of information to know about the product. Out of available sources of information - newspapers, television, price list and display are recognized as important. Friends are the most important sources of information in the category of word of mouth publicity.

\section{Objectives of the Study}

The objectives of the study include the following:

1. To investigate and identify the information sources sought by the customers for the purchase of two wheelers.

2. To identify the information source which have a positive influence upon the buying decision of the customers?

3. To analyze the demographic characteristics of the respondents and their relative effect on the information sources for the purchase of two wheelers.

\section{Scope of the Study}

The present research work is conducted within the Malappuram district of Kerala. According to 2011 census, Malappuram district have a population of $4,110,956$. At a population growth rate of $13.39 \%$, the district has a population density of 1,158 inhabitants per square kilometer. The census statistics also indicates a sex ratio of 1096 females for every 1000 males and a literacy rate of $93.55 \%$ in this district. Agriculture is the primary occupation of the 
people which is supplemented by other industries like timber industry, fishery, tourism, textile and spice trading. The income earned abroad by the native migrants in Middle-East is a significant source of revenue to the district. The main reason for selecting this location for study is that this place is one of the booming markets for two-wheelers in Kerala.

\section{Research Methodology}

This study covers a period of 5 years from January 2011 to December 2015. Both primary and secondary data are used for this study. Primary data spring from the concerned respondents of the present study using an interview schedule. A total of 1000 Interview schedules were prepared and circulated among the respondents. Out of this, only 714 interview schedules were filled up and collected. A scrutiny of these schedules led to the rejection of 33 interview schedules on account of incomplete responses. Thus 681 completed interview schedules were used for the present study. There for the actual sample size for the study is 681 .
Statistical tools like Chi-square analysis, ANOVA, Z-Test, Multiple Correlation, Multiple Regression and Friedman Test has been used for the meaningful analysis and interpretation of data using SPSS. Secondary data have been collected from various books, journals, research reports, magazines, websites and other records.

\section{Data Analysis and Interpretation}

\section{Socio-economic Characteristics and Two-wheeler Usage Pattern of the Consumers}

A proper knowledge of the social, economic, cultural, behavioral, demographic and psychographic pattern of the consumers are very much crucial for the clear cut understanding of the findings of a research project and its further successful implementation. The socio-economic characteristics and Two-wheeler usage pattern of the 681 Two-wheeler users surveyed here are as below:

Table 1. Socio-economic Characteristics and Two-wheeler Usage Pattern of the Consumers

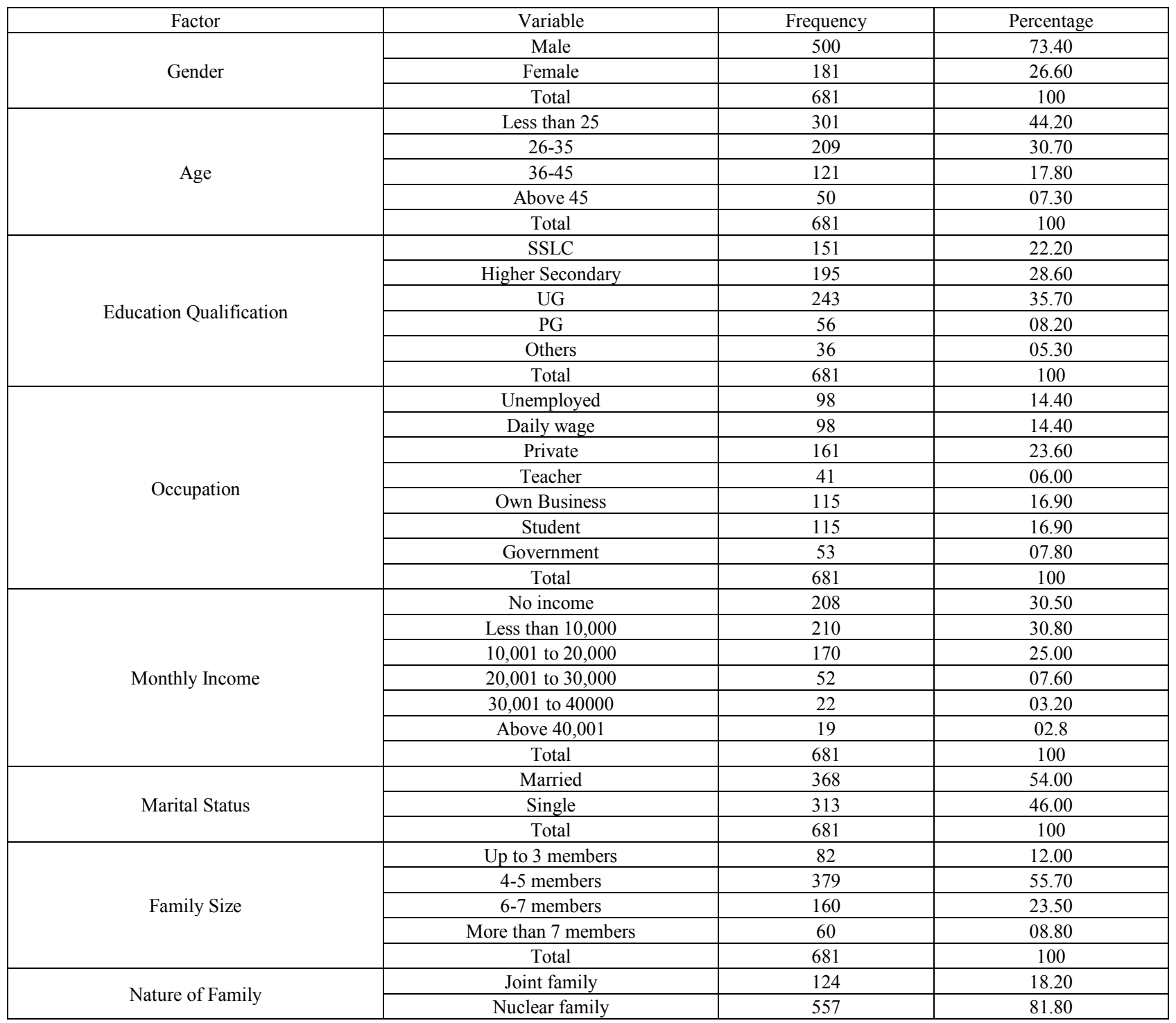




\begin{tabular}{|c|c|c|c|}
\hline & Total & 681 & 100 \\
\hline \multirow{3}{*}{ Regional Background } & Urban & 156 & 22.90 \\
\hline & Rural & 525 & 77.10 \\
\hline & Total & 681 & 100 \\
\hline \multirow{9}{*}{ Brand of Two-wheeler owned } & Hero & 285 & 41.90 \\
\hline & TVS & 55 & 08.10 \\
\hline & Yamaha & 68 & 10.00 \\
\hline & Suzuki & 37 & 05.40 \\
\hline & Honda & 150 & 22.00 \\
\hline & Royal Enfield & 16 & 02.30 \\
\hline & Bajaj & 58 & 08.50 \\
\hline & Mahindra & 12 & 01.80 \\
\hline & Total & 681 & 100 \\
\hline \multirow{3}{*}{ Type of Two-wheeler owned } & Bike & 365 & 53.60 \\
\hline & Scooter & 316 & 46.40 \\
\hline & Total & 681 & 100 \\
\hline \multirow{3}{*}{ First Two-wheeler ownership } & Yes & 546 & 80.20 \\
\hline & No & 135 & 19.80 \\
\hline & Total & 681 & 100 \\
\hline \multirow{4}{*}{ Duration of using the present Two-wheeler } & Less than 1 Year & 235 & 34.50 \\
\hline & $1-2$ Years & 129 & 18.90 \\
\hline & Above 2 Years & 317 & 46.50 \\
\hline & Total & 681 & 100 \\
\hline \multirow{3}{*}{ Point of Purchase } & Dealer & 476 & 69.90 \\
\hline & Sub dealer & 205 & 30.10 \\
\hline & Total & 681 & 100 \\
\hline \multirow{7}{*}{ Mode of Purchase } & Ready Cash & 403 & 59.20 \\
\hline & Bank Loan & 146 & 21.40 \\
\hline & Private Finance & 80 & 11.70 \\
\hline & Company Loan & 13 & 01.90 \\
\hline & Society Loan & 28 & 04.10 \\
\hline & Others & 11 & 01.60 \\
\hline & Total & 681 & 100 \\
\hline \multirow{4}{*}{ Price of Two-wheeler } & Less than 55000 & 229 & 33.60 \\
\hline & 55001 to 66000 & 291 & 42.70 \\
\hline & 66001 and Above & 161 & 23.60 \\
\hline & Total & 681 & 100 \\
\hline \multirow{6}{*}{ Displacement of Two-wheeler } & $100 \mathrm{CC}$ & 170 & 25.00 \\
\hline & $101-110 \mathrm{CC}$ & 171 & 25.10 \\
\hline & $111-125 \mathrm{CC}$ & 196 & 28.80 \\
\hline & $126-250 \mathrm{CC}$ & 127 & 18.60 \\
\hline & Above $250 \mathrm{CC}$ & 17 & 02.50 \\
\hline & Total & 681 & 100 \\
\hline \multirow{5}{*}{ Distance travelled per day in Two-wheeler } & Less than $20 \mathrm{Km}$ & 432 & 63.40 \\
\hline & $21-40 \mathrm{Km}$ & 163 & 23.90 \\
\hline & $41-60 \mathrm{Km}$ & 62 & 09.10 \\
\hline & Above $60 \mathrm{Km}$ & 24 & 03.50 \\
\hline & Total & 681 & 100 \\
\hline \multirow{5}{*}{ Avg. monthly expenditure on Two-wheeler } & up to Rs. 1000 & 377 & 55.40 \\
\hline & Rs. 1001 to 2000 & 216 & 31.70 \\
\hline & Rs.2001 to 3000 & 70 & 10.30 \\
\hline & Above Rs.3001 & 18 & 02.60 \\
\hline & Total & 681 & 100 \\
\hline \multirow{4}{*}{ Period of using a Two-wheeler } & 1-3 Years & 344 & 50.50 \\
\hline & 4-6 Years & 208 & 30.50 \\
\hline & More than 6 Years & 129 & 18.90 \\
\hline & Total & 681 & 100 \\
\hline \multirow{5}{*}{ No. of Brands considered } & 1 & 422 & 62.00 \\
\hline & 2 & 152 & 22.30 \\
\hline & 3 & 78 & 11.50 \\
\hline & 4 and above & 29 & 04.30 \\
\hline & Total & 681 & 100 \\
\hline \multirow{3}{*}{ No. of Two-wheelers owned } & 1 & 562 & 82.50 \\
\hline & 2 & 95 & 14.00 \\
\hline & 3 & 24 & 03.50 \\
\hline
\end{tabular}




\begin{tabular}{|c|c|c|c|}
\hline & Total & 681 & 100 \\
\hline \multirow{3}{*}{ Planning to buy one more Two-wheeler } & Yes & 113 & 16.60 \\
\hline & No & 568 & 83.40 \\
\hline & Total & 681 & 100 \\
\hline \multirow{3}{*}{ Planning to exchange the two-wheeler } & Yes & 164 & 24.10 \\
\hline & No & 517 & 75.90 \\
\hline & Total & 681 & 100 \\
\hline
\end{tabular}

Source: Primary data

Two-wheelers are mostly used by men than women. Hence the researcher has given emphasis to males for this study. 73 percent of the Two-wheeler users surveyed here are males. As Two-wheelers are more popular among the youth, that too in the age group of 15-35, almost 75 percent of the Two-wheeler users surveyed here are below 35 years of age. With respect to Educational Qualification 36 percent of the Two-wheeler users are Graduates while 50 percent of them comprises of higher secondary and below. Also majority of the Two-wheeler users are students with no income or working class with an income level less than Rs.20000. This clearly states that Two-wheelers are mostly preferred by students and the customers with a monthly income of less than Rs.20000. It is also clearly understood from the above table that 82 percent of the Two-wheeler users are members of Nuclear family and hence we can assume that Two-wheelers are mostly preferred by Nuclear family with a size f 3-4 members. It is a known fact that the rural customers are more inclined towards Two-wheelers than their urban counterparts because of poor rural road infrastructure and non-affordability of cars. In the present study also almost 77 percent of the Two-wheeler users surveyed are hailing from a rural background.

Table 2. ANOVA Table: Influence of Socio-Economic Factors and Two-wheeler Usage Pattern on Information Sources for Two-Wheelers

\begin{tabular}{|c|c|c|c|c|c|c|}
\hline Variables & Group & $\mathrm{N}$ & Mean & Std. Deviation & $\mathrm{F} / \mathrm{T}$ & P Value \\
\hline \multirow{5}{*}{ Age } & Less than 25 years & 301 & 50.6379 & 10.01591 & \multirow{5}{*}{4.913} & \multirow{5}{*}{$.002(*)$} \\
\hline & $26-35$ years & 209 & 52.1005 & 12.03458 & & \\
\hline & $36-45$ years & 121 & 49.1653 & 11.29922 & & \\
\hline & above 45 years & 50 & 45.9000 & 12.61397 & & \\
\hline & Total & 681 & 50.4772 & 11.19033 & & \\
\hline \multirow{8}{*}{ Occupation } & Unemployed & 98 & 50.7449 & 11.33766 & \multirow{8}{*}{2.231} & \multirow{8}{*}{$.039\left(^{*}\right)$} \\
\hline & Daily wage & 98 & 52.2551 & 12.5799 & & \\
\hline & Private Job & 161 & 51.0373 & 12.04206 & & \\
\hline & Teacher & 41 & 51.3902 & 10.62751 & & \\
\hline & Own Business & 115 & 49.2783 & 10.5569 & & \\
\hline & Student & 115 & 50.8957 & 8.91812 & & \\
\hline & Government Job & 53 & 45.9811 & 10.90429 & & \\
\hline & Total & 681 & 50.4772 & 11.19033 & & \\
\hline \multirow{9}{*}{$\begin{array}{c}\text { Brand of Two-wheeler } \\
\text { owned }\end{array}$} & Hero & 285 & 52.3439 & 11.96625 & \multirow{9}{*}{2.755} & \multirow{9}{*}{$0.008(*)$} \\
\hline & TVS & 55 & 49.5818 & 11.97944 & & \\
\hline & Yamaha & 68 & 49.6029 & 11.14643 & & \\
\hline & Suzuki & 37 & 50.4324 & 10.41777 & & \\
\hline & Honda & 150 & 48.4267 & 9.54421 & & \\
\hline & Royal Enfield & 16 & 44.8750 & 11.02648 & & \\
\hline & Bajaj & 58 & 49.4828 & 8.72432 & & \\
\hline & Mahindra & 12 & 53.2500 & 14.76559 & & \\
\hline & Total & 681 & 50.4772 & 11.19033 & & \\
\hline \multirow{2}{*}{ Type of Two-wheeler } & Bike & 365 & 49.4027 & 11.29643 & \multirow{2}{*}{-2.706} & \multirow{2}{*}{$.007(*)$} \\
\hline & Scooter & 316 & 51.7184 & 10.95357 & & \\
\hline \multirow{4}{*}{$\begin{array}{l}\text { Duration of owning } \\
\text { Two-wheeler }\end{array}$} & Less than 1 year & 235 & 51.4936 & 11.30818 & \multirow{4}{*}{5.871} & \multirow{4}{*}{$.003(*)$} \\
\hline & $1-2$ years & 129 & 52.3798 & 10.55876 & & \\
\hline & More than 2 years & 317 & 48.9495 & 11.18164 & & \\
\hline & Total & 681 & 50.4772 & 11.19033 & & \\
\hline \multirow{4}{*}{$\begin{array}{l}\text { Duration of changing } \\
\text { Two-wheeler }\end{array}$} & $1-3$ years & 344 & 51.1047 & 11.2851 & \multirow{4}{*}{3.613} & \multirow{4}{*}{$.027(*)$} \\
\hline & 4-6 years & 208 & 50.9087 & 10.82073 & & \\
\hline & More than 6 years & 129 & 48.1085 & 11.2966 & & \\
\hline & Total & 681 & 50.4772 & 11.19033 & & \\
\hline \multirow{5}{*}{$\begin{array}{c}\text { No. of Brand } \\
\text { considered for purchase }\end{array}$} & $0-1$ & 422 & 50.2085 & 11.01345 & \multirow{5}{*}{2.958} & \multirow{5}{*}{$.032(*)$} \\
\hline & 2 & 152 & 50.7368 & 11.99213 & & \\
\hline & 3 & 78 & 49.2949 & 10.60765 & & \\
\hline & 4 and above & 29 & 56.2069 & 9.64506 & & \\
\hline & Total & 681 & 50.4772 & 11.19033 & & \\
\hline
\end{tabular}

\footnotetext{
* Significant at 0.05 level
} 
Through the results of ANOVA test we could find that there is significant difference in the mean scores of information sources based on Age, Occupation, Brand of Two-wheeler owned, Type of Two-wheeler owned, Duration of ownership of the two-wheeler, Duration of changing the two-wheeler and Number of Two-wheeler considered for buying (from Table 2). It can also be understood that there is no significant difference in the mean scores of buying motives based on the gender, educational qualification, marital status, monthly income, size of the family, nature of family, regional background, point of purchase of the two-wheeler, mode of purchase, price of the two-wheeler, displacement of two-wheeler, distance travelled per day, average monthly expenditure on two-wheelers, intention to buy one more two- wheeler and intention to exchange the existing two-wheeler for a new one.

\section{Effect of Socio-Economic Variables and Two-wheeler Usage Pattern of the Respondents on the Information Sources for Two-wheelers}

Multiple regression analysis was used to find out the effect of several socio-economic variables and Two-wheeler Usage Pattern like Age, Sex, Educational Qualification, Occupation, Monthly Income, Marital Status, Size of the Family, Nature of Family, Regional Background, Brand of Two-wheeler owned, Type of Two-wheeler owned, Duration of using the existing Two-wheeler, Point of Purchase of the Two-wheeler, Mode of purchase, Price of the Two-wheeler, Displacement of Two-wheeler, Distance travelled per day, Average Monthly Expenditure on Two-wheeler, Duration of changing the Two-wheeler, No. of Brands considered before finalizing the existing one, Intention to buy one more Twowheeler and Intention to exchange the existing Two-wheeler for a new one on the information sources studied here.

According to Table 3, the Multiple Correlation value is 0.072 (r) which indicates that there is moderate level of correlation between buying motives and the set of predictor variables. $r^{2}$ value $(0.268)$ when expressed in terms of percentage shows that $26.8 \%$ of the variation in information sources has been explained by the set of independent variables.

Table 3. Multiple Regression Analysis: Effect of Socio-Economic Variables and Two-wheeler Usage Pattern of the Respondents on their Information Sources for Two-wheelers

\begin{tabular}{|c|c|c|c|c|c|}
\hline Variables & Mean & Std. Deviation & Regression coefficient & $\mathrm{t}$ & P Value \\
\hline Age & 1.88 & 0.95 & -0.13 & -2.10 & $.036(*)$ \\
\hline Gender & 1.27 & 0.44 & -0.03 & -0.52 & $.602(\mathrm{NS})$ \\
\hline Educational Qualification & 2.46 & 1.08 & -0.01 & -0.24 & $.809(\mathrm{NS})$ \\
\hline Occupation & 3.78 & 1.90 & -0.06 & -1.36 & $.175(\mathrm{NS})$ \\
\hline Monthly Income & 2.31 & 1.23 & -0.01 & -0.14 & $.885(\mathrm{NS})$ \\
\hline Marital Status & 1.46 & 0.50 & -0.06 & -1.10 & $.272(\mathrm{NS})$ \\
\hline Family Size & 2.29 & 0.79 & -0.02 & -0.39 & $.695(\mathrm{NS})$ \\
\hline Nature of Family & 1.82 & 0.39 & -0.01 & -0.24 & $.808(\mathrm{NS})$ \\
\hline Regional Background & 1.77 & 0.42 & -0.02 & -0.45 & $.652(\mathrm{NS})$ \\
\hline Brand of Two-wheeler owned & 4.08 & 2.17 & -0.13 & -3.23 & $.001(*)$ \\
\hline First time buyer & 1.20 & 0.40 & -0.02 & -0.28 & $.777(\mathrm{NS})$ \\
\hline Duration of usage & 2.12 & 0.89 & -0.04 & -0.78 & $.434(\mathrm{NS})$ \\
\hline Point of Purchase & 1.30 & 0.46 & -0.00 & -0.09 & $.933(\mathrm{NS})$ \\
\hline Mode of purchase & 1.75 & 1.16 & 0.07 & 1.80 & $.073(\mathrm{NS})$ \\
\hline Price of Two-wheeler owned & 1.90 & 0.75 & 0.07 & 1.29 & $.197(\mathrm{NS})$ \\
\hline Displacement of Two- wheeler & 2.49 & 1.13 & -0.08 & -1.34 & $.182(\mathrm{NS})$ \\
\hline Distance travelled per day on Two-wheeler & 1.53 & 0.80 & -0.01 & -0.32 & $.747(\mathrm{NS})$ \\
\hline Average Monthly Expenditure on Two-wheeler & 1.60 & 0.78 & 0.05 & 1.30 & $.194(\mathrm{NS})$ \\
\hline Duration of changing Two-wheeler & 1.87 & 1.12 & -0.07 & -1.67 & $.096(\mathrm{NS})$ \\
\hline No. of Brands considered for purchase & 1.58 & 0.85 & 0.07 & 1.76 & $.078(\mathrm{NS})$ \\
\hline Intention to buy one more Two-wheeler & 1.83 & 0.37 & -0.05 & -1.27 & $.205(\mathrm{NS})$ \\
\hline Intention to exchange existing Two-wheeler & 1.76 & 0.43 & 0.02 & 0.49 & $0.627(\mathrm{NS})$ \\
\hline
\end{tabular}

* Significant at 0.05 level $\mathrm{r}=0.072, \mathrm{r}^{2}=0.268, \mathrm{~F}=2.116^{*}$ 
When the individual correlation between information sources and other set of independent variables were calculated, it shows that the socio economic variables like Gender, Educational Qualification, Occupation, Monthly Income, Marital Status, Size of the Family, Nature of Family, Regional Background, Brand of two-wheeler owned, Type of two-wheeler owned, First Time Buying, Duration of using the existing two-wheeler, Point of Purchase of the two-wheeler, Mode of purchase, Price of the Two-wheeler, Displacement of two-wheeler, Distance travelled per day, Average Monthly Expenditure on two-wheeler, Duration of changing the two-wheeler, No. of Brands considered before finalizing the existing one, Total number of two-wheelers owned, Intention to buy one more two- wheeler and Intention to exchange the existing two-wheeler for a new one have very low correlation with buying motives. Whereas Age, Brand of two-wheeler owned and Type of two-wheeler owned have moderate correlation with buying motives.

The regression coefficient gives the effect of each of the independent variable separately on buying motives. Among the selected variables Age, Sex, Educational Qualification, Occupation, Monthly Income, Marital Status, Size of the Family, Nature of Family, Regional Background, Brand of Two-wheeler owned, Duration of using the existing Two-wheeler, Point of Purchase of the Two-wheeler, Displacement of Two-wheeler, Distance travelled per day,
Duration of changing the Two-wheeler and Intention to buy one more Two- wheeler have negative effect on the information sources.

Hence among the socio economic and Two-wheeler Usage Pattern variables Age, Brand of two-wheeler owned and the type of two-wheeler owned are chosen to be the predictor variables for information sources.

Through the use of Friedman Test the order of importance of the buying motives of the respondents towards Two-wheelers is understood from this descriptive table. In this table, the significance (.000) is less than 0.05 which means that the ranks given to the factors are not the same. We can clearly understand from this table that most of the customers are relying upon the feedback from existing two-wheeler users and word of mouth publicity as the most reliable sources of information on two-wheelers, followed by Internet and social media. The findings also reveal that two-wheeler mechanics, newspaper articles and automotive magazines are also considered as important sources of information on two-wheelers to the customers. As a shocking revelation, we can also understand from the above table that television advertisements are given least importance by the respondents as a reliable source of information on two-wheelers.

Table 4. Order of Importance of the Information Source for Two-wheelers

\begin{tabular}{|c|c|c|c|c|c|c|}
\hline Information Sources & Mean & Std. Deviation & Minimum & Maximum & $\begin{array}{c}\text { Mean } \\
\text { Rank }\end{array}$ & $\begin{array}{c}\text { Order of } \\
\text { Importance }\end{array}$ \\
\hline Television Ads & 3.0822 & 1.24345 & 1 & 5 & 6.85 & 10 \\
\hline Newspaper Articles & 3.1028 & 1.25135 & 1 & 5 & 7.26 & 8 \\
\hline Automotive Magazines & 3.047 & 1.3287 & 1 & 5 & 6.96 & 9 \\
\hline Two-wheeler Mechanics & 3.1938 & 1.30745 & 1 & 5 & 7.35 & 6 \\
\hline Internet & 3.3554 & 1.31059 & 1 & 5 & 7.94 & 3 \\
\hline Company Websites & 3.2349 & 1.33086 & 1 & 5 & 7.57 & 4 \\
\hline Social Media Page of Companies & 3.1615 & 1.33297 & 1 & 5 & 7.3 & 7 \\
\hline Social Media Discussions & 3.207 & 1.32166 & 1 & 5 & 7.44 & \\
\hline Word of Mouth Review & 3.4332 & 1.26561 & 1 & 5 & 8.25 & 2 \\
\hline Auto Exhibitions & 2.9236 & 1.22356 & 1 & 5 & 6.25 & \\
\hline Existing Two-wheeler Users & 3.7577 & 1.12264 & 1 & 5 & 9.30 & 11 \\
\hline
\end{tabular}

\begin{tabular}{|c|c|}
\hline \multicolumn{1}{|c|}{ Test Statistics } & 681 \\
\hline $\mathrm{N}$ & 842.245 \\
\hline Chi-Square & 14 \\
\hline df & 0 \\
\hline \multicolumn{1}{c}{ asymp. Sig. Friedman Test } \\
\hline
\end{tabular}


These revelations are sure to be an eye opener for the two-wheeler marketers as it tends to shake the conventional marketing principles and ideologies followed in the market today. Most of the companies use to spend millions of expenditure on advertisements and other sales promotional activities. But to their biggest amazement, the present study suggests that modern day customers have more faith on the genuine, right from the heart feedback given by the existing two-wheeler users and word of mouth reviews from their family members, friends, colleagues and relatives rather than the graphically articulated visuals in the television commercials or glossy promotional materials. Today what the customer seeking for is 'most accurate and reliable information' about the products they intend to purchase which these self-promoting television commercials of the two-wheeler companies never bothered to provide.

This theory is further substantiated by Omesh Chadha (2011) in his paper 'A Study of Consumer Buying Behaviour towards Bikes' in which realized that customers tends to seek opinion from the existing users while purchasing Bikes. It is also understood that friends and relatives occupy an important place among the various sources of information available to the respondents. Prialatha $\mathrm{P}$ and Malar Mathi $\mathrm{K}$ (2011) in their paper 'A Study on Consumer Preference for Two-Wheelers in Rural Markets of Coimbatore District' identified that the main source of information about a two-wheeler brand is Word of Mouth communication, irrespective of education level. Subhadip Sunil Maity (2012) in his study 'Study on Consumer Behaviour and Satisfaction Level of Two-wheeler with Reference to Bajaj Auto' also found that Word of Mouth Publicity is a major form of information for the purchase of two wheelers. Basavaraj $\mathrm{H}$. Huggi (2016) in his paper 'Recent Trends in Consumer Satisfaction towards TVS Motors with Special Reference to Ranebennur City' identified that Internet is the biggest source of information on two-wheelers to the customers. Chandu Ravi Kumar and N.D.N Swamy (2015) in their paper titled 'A Study on Consumer Satisfaction towards TVS Motors with Special Reference to Guntur City' realized the importance of internet and social media in influencing the consumers' purchase decision for two-wheelers. Chauhan V.S (2015) in his study 'A Research Paper on Impact of Social Media on Sales Promotion - A Case Study on Indian Automobile Industry' inferred that social media does have a significant impact on the sales and sales promotion of automobiles. Ketan Kamra (2015) in his paper 'Influence of Social Media on the Indian Automotive Consumers: Primary Study in National Capital Region' identified a strong influence of social media in influencing the consumers over multiple buying processes parameters. Sirajudeen M. and Leyakath Ali Khan U. (2015) in their paper titled 'An Empirical Study on Brand Position among Two-wheeler Motorcycles in Tiruchirapalli District' identified 'Word of mouth' as a major factor that influence the purchase decision for two-wheelers. Trinankur Dey and Dr. L. S. Sharma (2015) in their study 'An Empirical Study of Buying Behavior of the Two Wheeler Consumers in Agartala City' has also found that the customers are influenced by word of mouth by peer groups and, to some extent, by the salespersons at the point of purchase.

\section{Findings}

1. Most of the customers tend to gather maximum information on two-wheelers for making a final decision on which brand and model to be purchased.

2. Age and Occupation of the respondents have an impact on the sources of information about two-wheelers.

3. Brand of two-wheeler owned, type of two-wheeler owned, duration of ownership of the two-wheeler, the duration of changing the Two-wheeler and the number of brands considered before making the final buying decision also have some bearing upon the buying motives of the customers towards Two-wheelers.

4. Customers put more faith on the feedbacks given by the existing two-wheeler users and word of mouth reviews they gather from friends, family members, collegues etc. than any other sources of information.

5. Customers are widely using internet and social media for collecting information about the latest models of two-wheelers, reading online reviews, checking customer feedbacks, making comparisons of brands/models etc. before zeroing at a final choice and this process seems to influence their purchase decision.

6. Many of the customers seek the opinion and recommendation of two-wheeler mechanics about the best brands and models of two-wheelers available in the market before making a purchase decision.

7. There is an increasing tendency among the customers to read the reports and review articles in newspapers and automotive magazines for gaining more information about the latest models of two-wheelers available in the market and their features.

8. Customers tends to show a very low reliance upon television commercials of two-wheeler companies now a days, as they provide some biased, exaggerated and self-boosting information about their own products, which may not be right always.

\section{Conclusions}

Gone are those days during which the marketers tamed the minds of the customers to their favour using colouful television commercials with breathtaking visuals, pulsating punch lines and celebrity endorsement. Modern day customers are very shrewd and highly rational. Technological advancements have opened a wide variety of sources to them from which they can access information on any product to their fingertips within Nano seconds. They cannot be deceived any more with the graphical sorcery in the television commercials and the glittering promotional materials, offers or any such things. Today, the two-wheeler 
customers are very much concerned about the performance and quality of the bikes or scooters they intend to purchase than any other attributes. Instead of getting lured by the advertisements, they have started collecting information from all the available sources, with the help of which they make the most logical and rational purchase decision. They consider the feedbacks obtained from existing two-wheeler users, word of mouth review from their dear and near, ideas shared in social media and the expert opinion from the two-wheeler mechanics as the most accurate, unbiased and accurate sources of information for making the right choice of their two-wheeler. They have also started collecting data from internet, newspapers and automotive magazines to supplement their decision and to make their choice more precise and fine-tuned. Hence this seems to be the right time for the two-wheeler manufacturers, marketers and dealers to deviate from their conventional, standardized and self-boasting promotional gimmicks to more customized and customer centric strategies that reaches the prospects in the most efficient way. They need to streamline their marketing efforts in such a way that their existing (satisfied) customers speak for them and promote their products instead of wasting money on self- promoting advertisements and campaigns. It is a worldwide truth that nobody likes a person who boasts of himself, but everybody respects and put faith on a person who has a goodwill and reputation in the society. Similarly, the two-wheeler companies should stop boasting about themselves and should make others (customers and other stake holders) advocate for them. In order to realize this, the two-wheeler companies and dealers should provide 101 percent delight (not even satisfaction) to their customers or end users in terms of product quality and service quality there by motivating the customers to endorse that product on their own. Why celebrities? Let customers be the brand ambassadors.

\section{REFERENCES}

[1] Stanton, W. J, Etzel, M. J, \& Walker, B. J. 1991. Fundamentals of Marketing. 66-89, NY. McGraw-Hill.

[2] Kotler, P., Amstrong, G., Agnihothri, P. Y., \& Haque, E. 2012. Principles of Marketing: A South Asian Perspective. 73-112. New Delhi. Person.

[3] Basavaraj H. Huggi. (2016). Recent trends in consumer satisfaction towards TVS Motors with special reference to Ranebennur city. Imperial Journal of Interdisciplinary Research, 2(2): 49-55.

[4] Bhuvanesh Kumar., \& Kavitha. (2015). Customer satisfaction towards Honda Activa with special reference to Pollachi taluk. Intercontinental Journal of Marketing Research Review, 3(2): 11-18.

[5] Chadha, O. 2011. A study of consumer buying behaviour towards bikes. International Journal of Research in Finance \& Marketing, 1 (2): $86-101$.
[6] Chandu Ravi Kumar \& N.D.N Swamy. (2015). A study on consumer satisfaction towards TVS Motors with special reference to Guntur city. PARIPEX Indian Journal of Research, 4(9): 137-139.

[7] Chauhan V.S. (2015). A research paper on impact of social media on sales promotion - A case study on Indian automobile industry. International Journal of Management and Social Science Research Review, 1(11): 49-56.

[8] Christopher, A. J., \& John, F.S. 2013. Influence of peer in purchase decision making of Two-wheelers: A study conducted in Coimbatore. European Journal of Commerce and Management Research (EJCMR), 2 (1): 1-5.

[9] Gomathi, R., \& Gomathi, M. 2013. A study on customer preference and satisfaction towards Two-wheelers with special reference to RG Motors, Perundurai. Intercontinental Journal of Marketing Research Review, 1 (8): 1-8.

[10] Fahmeeda Yasmeen. (2015). Consumer behaviour towards brand positioning of two-wheeler bikes in Chennai city', Research Journal of Commerce and Behavioural Science, 4(11): 31-36

[11] Ketan Kamra. (2015). Influence of social media on the Indian automotive consumers: Primary study in national capital region. IOSR Journal of Business and Management, 17(8): $1-5$.

[12] Kumar, H.V., \& Babu, P.P. 2013. Impact of advertising on purchase of Two-wheeler: A study with reference to women in Chennai. International Journal of Advanced Research in Management and Social Sciences, 2(5): 178-190.

[13] Prialatha, P., \& Malar Mathi, K. 2011. A study on consumer preference for two-wheelers in rural markets of Coimbatore district. GIM Journal of Management, 1(1): 66-73.

[14] Priyanka Jain. (2015). A study of customer satisfaction of two-wheelers on Yamaha. IOSR Journal of Business and Management, 17(8): 08-19.

[15] Ramana, D.V, \& Subbaiah, P. 2013. A study on pre-purchase behaviour of two-wheeler motorcycle users in Nellore district, Andhra Pradesh. International Journal of Research in Commerce, IT and Management, 3 (12): 17-24.

[16] Soni, S. \& Soni, A. 2012. Consumer behaviour towards two-wheeler bikes - A comparative study of rural and urban consumers of Jodhpur district of Rajasthan. Global Research Analysis, 1 (7): 91-92.

[17] Yuvaraju, D., \& Rao, D.S. 2014. Customer satisfaction towards Honda Two Wheelers: A Case Study in Tirupati. IOSR Journal of Business and Management, 16 (5): 65-74.

[18] Agarwal, A., Alok, A., Karian, C., \& Sinha, S. 2012. A study on the key buying factors that influence the customers towards the purchase of Two-Wheeler in urban Areas. Unpublished MBA Dissertation. Alliance University, Bangalore.

[19] Sharma, K. 2010. Market survey on the decision making process purchase the motorcycle among the resident of the Jalandhar city. Unpublished MBA dissertation, Punjab Technical University, Jalandhar.

[20] Sirajudeen M. and Leyakath Ali Khan U. (2015). An empirical study on brand position among two-wheeler motorcycles in Tiruchirapalli district. Primax International 
Journal of Commerce and Management Research, 3(2): 10-13.

[21] Trinankur Dey and Dr. L. S. Sharma. (2015). An empirical study of buying behavior of the two-wheeler consumers in Agartala city. Research Revolution - International Journal of Social Science and Management, 3(8): 52-58.

[22] Velumani M. (2015). A study on consumer buying behaviour and satisfaction level of two-wheeler with reference to Suzuki motorcycle at Erode. International Journal of Business and Administration Research Review, 1(12): 85-92.

[23] Arish, A.S. (2008, Feb 8). An analytical study of consumer behaviour while buying motorcycle. Retrieved from http://www.blog.skylinecollege.com/blog/consumer-behavio r-study/an-analytical-study-of-consumerbehavior-while-buyi ng-motorcycle. 